\title{
THEOLOGICAL KNOWLEDGE IN ISLAMIC MYSTICISM AND GNOSTICISM
}

\author{
Fereshteh Jafari
}

\author{
Departemen of Persian Literature, Naragh Branch \\ Islamic Azad University, Iran \\ fereshte.jafari7@gmail.com
}

\begin{abstract}
In this paper, the similarities between the Gnostic and Islamic mystic beliefs about "Knowledge" (Ma'refat) will be considered. The aim is to answer the question of whether they share a common view of divine knowledge. For this purpose, first Gnosticism and its ideas will be clarified. Second, a brief history of Islamic Mysticism will be presented. Then, in light of the evolution path of such beliefs, the main principles of both cults about the Gnosis and Mysticism will be reconsidered. The methodology of this study is based on a comparative study, by analyzing Islamic mystical books and Gnostic texts. Through the study of mystical books, the traditions and beliefs of the early mystics, in this case, are stated, and some examples from the Gnostic books about the Gnosis and mystical knowledge are mentioned. The comparative study of these two religions revealed that they have many similarities in points of view to "knowledge". Similarities between Islamic mysticism and Gnosticism are so much that some believe that the theory of divine knowledge in the minds of Muslim Sufis originates from Gnostic ideas. But this claim cannot be completely true and the Gnostic beliefs have only had influences on it.
\end{abstract}

Keywords : Islamic Mysticism, Gnosticism, Gnosis, Knowledge

\begin{abstract}
ABSTRAK
Dalam tulisan ini, kesamaan antara kepercayaan Gnostik dan mistik Islam tentang "Pengetahuan" (Makrifat) akan dipertimbangkan. Tujuannya adalah untuk menjawab pertanyaan apakah mereka memiliki pandangan yang sama tentang pengetahuan ilahi. Untuk tujuan ini, Gnostisisme pertama dan ide-idenya akan diperjelas. Kedua, sejarah singkat Mistik Islam akan disajikan. Kemudian, dalam terang jalur evolusi keyakinan tersebut, prinsip utama dari kedua aliran tentang Gnosis dan Mistisisme akan dipertimbangkan kembali. Metodologi penelitian ini didasarkan pada studi banding, dengan menganalisis kitab-kitab mistik Islam dan teks Gnostik. Melalui studi tentang buku-buku mistik, tradisi dan kepercayaan mistik awal, dalam hal ini, dinyatakan, dan beberapa contoh dari buku-buku Gnostik tentang Gnosis dan pengetahuan mistik
\end{abstract}


disebutkan. Studi perbandingan kedua agama ini mengungkapkan bahwa mereka memiliki banyak kesamaan dalam hal "pengetahuan". Kemiripan antara mistisisme Islam dan Gnostisisme begitu banyak sehingga beberapa orang percaya bahwa teori ilmu ketuhanan dalam benak para sufi Muslim berasal dari ide-ide Gnostik. Tetapi klaim ini tidak dapat sepenuhnya benar dan kepercayaan Gnostik hanya berpengaruh padanya.

\section{Kata-kata Kunci : Mistisisme Islam, Gnostisisme, Gnosis, Pengetahuan Introduction}

The name "Gnosticism," is derived from gnosis, the Greek word for "knowledge." The emphasis on knowledge as the means for the attainment of salvation, or even as the form of salvation itself, and the claim to the possession of this knowledge in one's own articulate doctrine, are common features of the numerous sects in which the gnostic movement historically expressed itself (Jonas 1991, 32). And the term 'mysticism,' comes from the Greek mystes, meaning "to conceal." In early Christianity the term came to refer to "hidden" allegorical interpretations of Scriptures (Gellman 2017, 1287). In Classical Greece the rites of the mystery religions were largely or wholly secret. The term mystes is itself derived from the verb myein "to close," especially the eyes or mouth) and signified a person who kept a secret (Williams 2017). In Persian language, Mysticism means "Erfān" that is derived from "Ma'refat" and it is a kind of esoteric knowledge.

It has been said that mysticism is as old as human life and is not limited to any nation or religion. Baumgart believes: "Mysticism is not associated with anything but a basic experience that is: "the unity of human with the infinite, the unity of human consciousness with the absolute truth, mystical unity or spiritual wedlock, in which mankind tries to lose his identity in a life much greater than his own lives." This great dream, trying to become a divines, desires to fuse the spirit and human as an absolute and it is arguably one of the central motifs of mystics in all ages and all lands" (Ashtiani 2007, 10).

Mysticism can be considered as the common form of all faiths and religions. Therefore, there are many links and commonalities among spiritual religions of the world, and these commonalities in Islamic and Gnostic mysticism are more abundant. Mehrdad Bahar believes that Gnosticism and Manichaeism have had a great effect on Islamic mysticism and profound connections between these two parts can be observed the history of mysticism in Western Asia. He thought Zorvanism, Mithraism and Manichaeism have had mystic foundations and have a profound effect on Iranian culture (Motlagh 2000).

The cultural, religious and ideological impacts of Gnosticism in Iran began since the late third century AD, after the conviction and death of Mani. Appearance of Gnosticism among the Muslims began from the first HA century. 
Probably one of the ways that Gnostic had influences of ideological influences on Muslims was the religion of Manichaeism from the third century to the ninth century AD, which given a very wide influences from the Roman region to China. In addition, Mandaean had an important role to disseminate of Gnostic and Hermetic ideas among Muslims. The Gnostic ideas were penetrated through Syria, Mesopotamia, and Asia Minor to the Persian Muslim mystics. This effect was greater on Ismailia faith. Ismailia was the first group of Muslims in the ninth century that were under the influence of Gnostic and Manichaean ideas.

Among the items that can be used by researchers, some works have been written by the opponents to reject the Gnosticism. Those works which directly contain the Gnostic ideas have been discovered at Nag Hammadi in the Upper Egypt, inside of a clay jar. There were several old papyruses. Researchers believe that these texts are Gnostic writings, which date back to 16 centuries ago when the Gnostic church was in conflict with the Orthodox Church, and were hidden to avoid the danger of destruction. Many researchers have tried to translate the proposed texts and in 1981, James Robinson represented a full translation of all texts and manuscripts (Robinson 1981).

One of the main resources on studying the Gnosticism is the Dictionary of "Gnosis and Western Esotericism" edited by Wouter Henegraff (Hanegraaff 1967). Also, in some preliminary work was carried out by Jonas in 1943, it has reviewed the Gnostic religion and its origins were attributed to the ancient Persia, Babylon and Egypt. Ignác Goldziher in 1910 studied the effects of "NeoPlatonism and Gnostic Beliefs on Hadith" (Goldziher 2007). Esmailpour in his essay " A Comparative Study of the Spiritual Masnavi and the Manichaean Gnostic Poems", has studied the Gnosticism in the Masnavi preface and It has been concluded that there is certainly a commonality between the Gnostic mystical themes and Rümi's ideas (Motlagh 2002). "Hymn of the Pearl" is a gnostic element that its effect and use on Iranian mysticism has been studied in "Hymn of the Pearl and Iranian Mysticism" from Mehran Kondori. (Kondory 2016). F. Jafari and M. Ameri in their essay "Impact of Gnosticism among Muslim Mystics" wrote about the Gnostic mysticism as well as Islamic thoughts and briefly studied the effects of Gnosticism on Islamic mysticism (Jafari \& Ameri 2017). "Allegorical Motifs-Mystical Gnostic in Book Jamshid and Khorshid Salman Savedji" by Z. Rajablou and M. Alimi, in this article the influence of Gnostic themes, including the duality of matter and spirit, love, sleep, travel, mediating and testing were shown (Rajablou \& Alimi 2017). R. Zarrinkoob and Hosseini in their essay "A look at Eschatological Individual Beliefs in Gnostic and Manichaean Teachings" have studied the beliefs about the other world in Gnosticism (R. Zarrinkoub \& Hoseini 2018). Other research is "A Comparative Study of "God-like Man" Based on Sufism, Kabbalah and Gnosticism" by Shahbazi and Abedi, This paper contains a comparative study of god-like man under such interpretations 
as Adam Kadmon, Anthropos and the first man in Jewish mysticism, Gnosticism and Sufism (Shahbazi \& Abedi 2020).

This paper aims to highlight the similarities of these both Mystical approaches by evaluation the prominent ideas of both sides about divine knowledge. For this purpose, the most important mystical texts like Kashf alMahjūb, Tadhkerat Al-Awliya, Resaleye Ghoshairieh and the view point of Muslim mystics like Molana, Ibn 'Arabi, Ghazāli had been reviewed and compared with the Gnostic ideas.

\section{Gnosticism}

The Gnostic tradition was developed originally in Alexandria and Samaria. The Gnosticism was spread by Simon the Magus in Samaria, and in Alexandria, it was spread by Basilides, and Valentinus in the second century $\mathrm{AD}$ that all of them were great Gnostic missionaries in this period. Along with them, Marcion, within the Roman Empire, was the leader of the Gnosticism.

Although, there were some disagreements on some aspects such as the world creation as well as fall and salvation of humanity, Gnostic religions have shared the opinions under the influences of esoteric religions and relying on the concept of Savior knowledge.

The origins of the Gnostic faith are controversial. Some search its origins in the ideas of ancient Persia (Duchesne-Guillemin 1996, 330) and others believe that it was influenced by Jewish mysticism (Quispel 1992, 1-19).

F. Ch. Bauer (1831) and Lassen (1858) sought to prove the relation between Gnostic faith and Indian religions; Lipsius (1860) pointed to Syria and Phoenicia as its home, and Hilgenfeld (1884) thought it was connected with later Mazdeism. Joel (1880), Weingarten (1881), Koffmane (1881), Anrich (1894), and Wobbermin (1896) explored the rise of Gnosticism by the influences of Greek Platonic philosophy and the Greek mysteries, while Harnack described it as "acute Hellenization of Christianity". For the past twenty-five years, however, the trend of scholarship has steadily moved towards proving the pre-Christian Oriental origins of Gnosticism (Herbermann 1907, 1287).

But through the study of Gnostic beliefs, this can be concluded that, this religion is in fact a consolidated religion of different Eastern ideas such as Zoroastrian dualism and Jewish mysticism as well as Iran - Christian Salvation ideas, Hellenistic philosophy etc. (Jonas 1991, 33).

The common motifs in the Gnostic religions derived from the phenomenological studies which included: believing in two opposite fundamental principles, whether be partners in eternity or not, the myth of 
Fall of Soul, the shine of heavenly light, being stranger in the world which is an expression of the feeling of exile or wanting to escape from prison of physical body, the theory of Gnosis, the salvation gnosis that make the human to be aware of their true nature and be saved; this salvation is the key to re-enter into the initiated city of God (Decret 2004, 39).

Gnosticism is based on the conflict of spirit and matter and it says that the creation of the material world was not by the Almighty God; rather, there is another God who is actually much lower than the Almighty in the hierarchy. The Gnostics believed in a great and unknown God who was not involved in the creation of this world. They believe that another God created the physical world, called "Demiurge", and some say that the material world is created by demon, so the world is evil; they also believe that human is made by forces of Hell and the light is imprisoned in the body, and his mission is to save these fragments of light to be able to achieve the Paradise of light (Motlagh 2001, 71).

Gnostic religion is based on revelation, illumination, and the duality of source, i.e. two principles of good and evil. The salvation of human and his soul from the material world and nature are the main core of Gnostic beliefs, and based on, the return of the soul to the world of light is through the truth and piety in this world. "Gnostics began to talk about a kind of dualism and believe that the soul and the body are completely separate. They said that the material world is so wicked and defiled so, it is not the dignity of God to create such a bad creature" (Noss 2011, 628).

Zarrinkoub says that Gnosticism is a belief about the battle over evil: "When a Gnostic sees himself surrounded in a world of evil, he finds himself a stranger and prisoner in this world, so he will revolt against the tenebrous world" (A. Zarrinkoub 2011, 23).In this portrait, the human with a dualistic nature, imprisoned a part of the divine light in his natural body. In this universe, he is so far away from the very early origin, and has lost and forgotten his father and the desired place of himself, and needs to be saved. Saving is in fact, the process of returning and unifying with the origin (MacRae 1970,143).

Gnostics believe that in this world the divine exists within us as flams of lights which once were originally blazing but has been shut off in the matter, until the time it appears in other forms and shines (Naini 2005, 75). One of the important issues, and indeed the main pillar of this Gnostic faith, is achieving the "complete knowledge", so that the school is called the "Agnostic philosophy" (Adrieh) and its followers are called "Gnostics" (Adrion [ædrju:n]) (Nicholson $2003,299)$. Gnosis is the knowledge of the divine mysteries which is given to a chosen one (Hanegraaff 1967, 895). 


\section{Islamic Mysticism}

Islamic mysticism is an illuminative knowledge of God and is the way to achieve the degree of divine proximity. In the early days of the emergence of Islamic Sufism, it was a practical cult not a theoretical. It means that the first Muslim mystics believed that faithfully performance of religious commandments and piety are medium to achieve divine Knowledge

Some believe that Rabia (100-180 AH /717-801), was the initiator of romantic mysticism that her romantic litany has been about divine love, passion and death. From the third century AH, with the advent of mystics such as Yazīd Basțāmi (161-234 AH / 804-874) and Mansoor Ḥallāj (244-309 AH /858-922) and Abusaeid Abolkheir (357-440 AH / 967-1049) gradually fear of Allah and asceticism were replaced by the divine love and ecstasy and dance (Sama). Finally, with the advent Ibn 'Arabi (560-638 AH /1165-1240), the Discussion of Knowledge (Ma'refat) has been highlighted. In fact, Ibn 'Arabi modified mysticism into a regular school. At the beginning of the seventh century AH, Mongol invasion was an important reason for the spread of Sufism among Iranians. The seventh century AH was the glory of Sufism. In this century with the advent of the great scholars such as Ibn 'Arabi (560-638 AH /1165-1240), Rūmi (586-652 AH/1207-1203), Șadr al-Dīn al-Qūnawi (607-673 AH/12071274), Fakhruddin 'Irāqi (610-688/1213-1289) and..., many valuable works in the field of mysticism were written.

Tasavof (Sofism) adverted to political and social aspects and it immersed in heresies, customs and appearances as well. However, some Shi'a scholars had expertise in theoretical mysticism, such as Mulla Șadrā Shīrāzi (980-1045 AH/1572-1640) and Molla Mohsen Feyz Kashāni (1007-1090 AH /1598-1680) whom were not attributed to any Sufi sects.

The origins of Sufism and its beginning have been considered as the critical issues for researchers. Some researchers believe that Iranian-Islamic mysticism is completely affected by Manichaeism and Gnosticism or other mystical cults, But Some believe that the main source of doctrines and beliefs of Islamic mysticism derived from Quran, Hadith and traditions of the Prophet under the affections of other mystical beliefs have gradually created a new school that is proper to the nature of all people, as well as being opposed to all prejudices.

Mysticism and its development in Islamic countries have a very long history that has been started from the beginning of the Islamic era, and it has continued until recent centuries; and there are great differences between beliefs and doctrine of various Mystical sects. But in this research, it is not possible to discuss this history in greater details. 


\section{Knowledge in Islamic Philosophy and Beliefs}

In Iranian and Islamic beliefs, the path to the knowledge is limited to four schools:

1. Peripatetic school by Avicenna, that believes logical reasoning is the only way to truth, and is called "Philosophy of Argumentation".

2. 'Ilm al-Kalām (Science of Discourse), in which accepting the religious orders and the Shari'ah of the Prophet, through the reasoning and argument, is considered as the path to the truth.

3. Rūmi's mystical method, that the self-purification and intuition of heart is considered as the way of reaching to the truth.

4. Illuminationist or Ishraqi philosophy of Shahāb al-Dīn Yahya Suhrawardi, that was influenced by Peripatetic school of Avicenna and mysticism, and was a combination of these two. This philosophy is considered as "Spiritual philosophy". It is emphasizing on the intuitive aspects of intellect, and philosophical knowledge which is gained by shedding light on the intellect. (Mohammad \& Rezza 2012, 103-126)

In transcendent theosophy (al-Hikmat al-Muta'āli), developed by Mulla Șadrā, the two perspectives of Peripateticism and Illuminationism with Sufiism of Rūmi are put together and generate a great knowledge methodology in which all faculties of knowledge in the hierarchy of passing from the carnal matter to the spiritual matter are included (Nasr 2016).

Mulla Șadrā distinguishes between intuitive knowledge that can be achieved through the heart, and the prophetic knowledge that comes through the revelation: He believed that the way to the knowledge can be summarized in three main ways: reason, revelation and inspiration. These three methods are distinct methods of gaining knowledge and truth; and each served its part in explaining the felicity and guidance of human (Shīrāzi 1982, 70).

But he believes that the path of revelation and mysticism is more confident and more reliable than the path of intellect and argument. He considers the intuition prophetic revelation as the most reliable and convincing way to gain the knowledge, and a criterion to measure the accuracy and truth of other mystical revelations and observations (Shīrāzi 1987, 29). 
In the viewpoint of Islamic verses and traditions, the heart is the seat of knowledge or a tool to gain it: " $O$ men, now there has come to you an admonition from your Lord, ad a healing for what in the breasts, and a guidance, and a mercy to the believers". (Yūnus, 57)

Also, the knowledge that is gained by the heart, will be held worthy before God: "God will not take you to task for a slip in your oaths, but He will take you to task for what your hearts have earned". (Baqare, 225)

And only the heart that is eager to knowledge is praiseworthy, as the Prophet (PBUH) has said: "Blessed is the one whom keeps his heart greedy [to the knowledge]".

\section{The Theological Knowledge}

One of the aspects that is mutual between Islamic Sufism and Gnostic faith is the belief in the Saviour knowledge. The Gnostics believe that the human soul is divine and an eternal element. But mankind has forgotten his nature and his divine principle. In this world, human mission is to free the spirit, and it can be done just through the gnosis. The Gnostic ideas were based on illuminated knowledge and revelation and particularly creational beliefs which help human soul to get rid of the material world and reach the divine one; to achieve this, it needs asceticism and no attention to the worldly blessings.

Nicholson believes: although there is no clear evidence that shows the prominent position of the Theory of Knowledge in Early Sufi but, suggests the connection between them and the Gnostic tradition (Nicholson 2003, 52).

The concept of "knowledge" for a Sufi is the "Gnosis" for Gnostics, which is the immediate knowledge of God based on revelation and illumination. Such knowledge is not the result of rational and mental processes and depends on the will of God, and will only be granted to those who are vulnerable and worthy to receive the knowledge.

In Manichaean myth the ancestor of human is evil and has a dark nature, and gnosis is the knowledge of such dark and evil nature. Therefore, the followers of this idea were called Gnostics, which means "Those who are aware of their lost in the dark and the material world." (Motlagh 2007, 199).

The salvation of mankind in Gnosticism obtained by Gnosis, and inner brightness, believing in the teachings of the messengers of light, and guidance which brings the fruit of knowledge for human. "Gnosis" is in fact a revelation, the inner revelation that reveals the divine secrets for the mystic. 
Gnosis is a heavenly gift of God to man who is incomplete until he would wake up and remember what he has forgotten. Gnosis, as the Hymn of the Pearl says, is a letter sent by the prince in a form of a bright divine to his forgetful child to recognize his royal origin:

From the (thy) Father the King of kings, and thy mother the queen of the East, and thy brother that is second unto us; unto our son that is in Egypt, peace. Rise up and awake out of sleep, and hearken unto the words of the letter and remember that thou art a son of kings; lo, thou hast come under the yoke of bondage. Remember the pearl for which thou wast sent into Egypt (Lambdin et al., 2009).

According to Gnostic ideas, in spite of the fact that the Father of all or the almighty God is unknowable in his nature, he wishes to provide knowledge and make Himself known. But this revelation is a gradual process, and it is not direct but mediated. This self-revelation is intended to inspire a constant searching after the Father, even though the Father's primordial essence is unsearchable. Thus, it is by the will of the Father that the Father is known, because he breathes a spirit in all things that creates in them the idea of seeking after the Unknowable, so that they are drawn to him as if by a sweet aroma (Turner \& Majercik 2000, 288).

From the mystic point of view, the essence of God is beyond knowledge and just His names and attributes can be understood. This is why the elders have advised that we should not think about the essence of God "Think of God's creation and not about God, or you will die" (Al-Suyūṭi ND, 514). Ibn 'Arabi has said: "Essence in itself has no name and may not be known at all, because it cannot be affected by anything. But the knowledge of essence is forbidden for all but God. Because "No one knows God, but God", so the names are with us and for us. They circle around us and are manifested through us. Their principles are upon us, we are their goals, their sights are with us and their beginning is with us. But thinking about the Essence of God is impossible; therefore, we just can think about the creatures. Thinking is just for The Most Beautiful Names (Asmāal Husnā) and Sight of creatures. All Names are the basis of creatures" (Chittick 2009 , 8). Mystics believe that the true nature of God is not known and god can only be known through the implications. "Dhū-Nūn al-Mișri has been told that, how you know God? He said: I know God through God, and if the mercy of God was not with me, I would never know him" (Qusheiri 2008, 570).

The Muslim mystic tries to gain a deeper knowledge about God, so he tries to know the material phenomena so he will be able to know the divine attributes, because the Good's Essence is unknown. From the mystic's point of view, the expression of God in the universe is in two forms, one is the manifestation of the beauty and the other is the manifestation of the glory. Some events are the 
expression of the manifestations of God's mercy and some are Manifestations of his anger traits.

\section{Self-Knowledge}

Sufis believe that human is in place of God on earth and is trusted for the divine trust. This creature consists of two different natures, animal and Angel. The Angle nature of mankind is known under different names in different rituals. In Hermeticism, this Angle nature is called the "complete nature" and is the heavenly ego, which is the key knowledge, and the true knowledge can be found only through this ego.

According to Sohrevardi, what brings the Gnostic Knowledge to Hermes is his "Complete Nature" (Corbin 2008, 42). The complete nature is the divine super ego of human that is heavenly, and through that knowledge human can know their true God: "The one Who knows himself he can know his God" (Majlesi 1983, 32).

Quispel believes that the Gnosticism from Hermes to Mani is nothing but an imagined experience of meeting self, and it has been mentioned in the Hermetic texts that "One who knows himself, knows everything" (Quispel 1992, 1-19).

In the Gospel of Thomas, read: "If those who lead you say to you: 'Look, the kingdom is in the sky!' Then the birds of the sky will precede you. If they say to you: 'It is in the sea,' then the fishes will precede you. Rather, the kingdom is inside you, and outside of you. When you come to know yourselves, then you will be known, and you will realize that you are the children of the living Father. But if you do not come to know yourselves, then you exist in poverty, and you are poverty" (Robinson 1981, 74).

Monimus, the Gnostic teacher says: "Leave the seeking about God, creation and other similar issues, learn who is inside you who does anything" (Holroyd 2008, 222).

Also, for Muslim mystics, the key to know the almighty God is to know the self. In Kimiya-e Sa'ādat, under the chapter of Knowing Self, it says: "If you do not know yourself, how are you going to know your Lord? If there is nothing closer to you than yourself, if you do not know yourself, how you are able to know anything else?"(Ghazāli 2001, 13-14).

The source of knowledge is the pure heart, and it is able to be gained through the revelation. Mystics believe that if humans become aware of their hearts, and know themselves, they will know the almighty God as well. Yazìd Basțāmi says: "I wish people could know themselves; the knowledge is through the knowing of themselves.'('Atțār 2005, 196). 
The author of Kashf al Mahjüb believes that the way to know God is knowing Self (Nafs): "It is incumbent upon all seekers of the Truth, to acquire its knowledge, because whoever is ignorant of himself is yet more ignorant of other things; and as much as a man is bound to know God, he must first know himself, in order that by rightly perceiving his own temporality he may recognize the Eternity of Allah and may learn the Everlastingness of Allah through his own annihilation" (Hujwiri 1997, 248).

As Henry Corbin says: "What a man acquires in the mystical experience, is the divine pole of his own, which is his ego as a self that God in the first day, in the unseen world, manifested himself in and through him; and he has become in appearance by him and this appearance is the face that represents God in material appearance" (Corbin 1979, 86).

The Quran also mentions that humans have their own treasures inside, and messengers were sent to make them remember these facts and clean the dust of negligence and ignorance of the human mind to attain the light of knowledge."We will show them Our Signs in the universe, and in their own selves, until it becomes manifest to them that this (the Qur'an) is the truth." (Fușșilat, 53)

To know God, one needs to know the self, and knowing the self would not happen unless he leaves all constraints and determinations. Then he will be drowned in the unlimited existence of God. Because the unity and solidarity will happen between two existences, it happens when one of them leaves itself, and goes beyond the existence of itself. Knowledge is just in the stage of Names and Attributes, and The Essence will always remain unknown; the recommendations of mystics for knowing God is, based on the traditions, human is a divine creature and his existence is the collection of all divine Names and Attributes. Therefore, by Self- recognition, human will know the Names and Attributes of God not his Essence.

'Arif (the mystic) believes that knowing the self is the highest level of knowledge: "One who knows himself will know God" (Rūmi 1984, 2114).

Though he dies, his sight is everlasting, because his sight is the sight of the Creator.

That light by which he sensibly beholds his own face (reality) before him, is not the light of sense (Rūmi 1984, 884).

\section{Illuminated Knowledge}

The most important and common elements among most mystical religions are illuminated knowledge and intuitive revelation. Because it believes that the scientific understanding is not enough to obtain the knowledge, and the wisdom can be found only through meditation and revelation. The mystic is 
always looking for a more direct and closer relationship with the true God. He is someone who has achieved the truth through genuine intuitive knowledge, but its appearance is not important to him.

Gnostics like Muslim mystics make a distinction between the intellectual knowledge and illuminated knowledge; in their view, the gnosis is the second one which is the illuminated and intuitive wisdom which can be called "insight". Muslim mystics believe that the knowledge is the secret of creation: "I was a hidden treasure. I was seeking to be known. So, I created the creature to become known" (Ibn 'Arabi ND, 112). The purpose of the mystic is to know God, but not through the senses or intellect; because God is not material that could be known by the senses, and is not limited to understanding. In Hermetic beliefs, God is the Great Wisdom and human is asked to immerse themselves in the divine wisdom of God and become fully conscious of God: "To realize Atum (the God), you should be shared in his identity, because the doublet actually seeks its other. Leave the material world and remind yourself, you are so valuable" (Freke \& Gandy 2005, 186).

The Greek philosophers and most Christian theologians believe that although God unknowable in his essence, He could, at least partially, be comprehended by the human mind (nous), through philosophical reasoning and contemplation of the cosmic order; but the Gnostics denied this and declared knowledge of God to be possible only through revelation (Hanegraaff 1967, 405). The illuminated knowledge of Gnostics is an unknown knowledge, absolutely free of rational argument (Wallis \& Bregman 1992, 448). Sufism believes that what leads human to the knowledge of God is just God, and the intellect and science are weak in this way; as the limited mind and science of human cannot understand the unlimited existence of God. In such a point of view, the Gnostic is the one whose "has been sanctified and enlightened by the light of God and has been received the gift of seeing God" (Lambdin et al., 2009).

God is the true owner of the glory and beauty, and the way to have him is through love and not reason. That is why the Sufi mysticism deals with love and passion, and is elusive of reasoning and discussion. The Súfi's book is not (composed of) ink and letters: it is naught but a heart white as snow (Rūmi 1984, 159).

The mystic faith is a certain one, since it is an immediate inspired faith by God. The way of mysticism and the only way to reach true knowledge, for mystics, is revelation and illumination through the heart; and its purpose is to make a direct connection with the Essence of God and negation of the physical characteristics.

According to Zarrinkoub, the tendency of Sufism to the inner knowledge is in fact a rebellion against two common ways of knowledge in that era: the 
narrative and visual knowledge which was represented by the Sunnah and Hadith believers, and intellectual and dogmatic knowledge that Mu'tazilites and translators of Greek books rely on that (A. Zarrinkoub 2011, 29).

Muslim mystics believe that only the heart that is eager to knowledge is praiseworthy, as the Prophet has said: "Blessed is the one whom keeps his heart greedy [to the knowledge]" (Nasr 2016), and to receive the divine illuminations and lights, the mirror of the heart should always be pure and free of earthly passions. Cleaning the mirror of the heart is possible by night praying and reading Quran and spiritual attempts. The revelation is through the light and this is the light of God which has been sent to the human's heart, and is in correspondence with the inner light of mankind.

Revelation is, in fact, removal of the worldly barriers and entering the beyond of this world, where the soul of Arif can be connected to the unseen phenomena and the unseen world, and each time new doors of understanding would be opened for him. The mystics who have experienced the revelation and illumination, talk about their spiritual experiences and what is seen not heard, what is felt by the heart, not understand by the mind.

The subject of knowledge is not the world of senses, but the world beyond the senses, and the way to understand this world is in sight, not reason. The area of intellectual understanding is the world of senses. According to the mystics, what is in the world of beyond sense belongs to beyond the reason. What is worthy in the region of beyond reason, is the passion and individual revelation.

In addition to Ibn 'Arabi's words, believing the land beyond reason is also mentioned in the works of Ghazāli. He writes in "Al Munqidh Min al-Dalāl": there is the other land beyond reason, where another eye opens for man, which can see the unseen as well as the future. But just like the senses of human which cannot understand the contemplatives, the mind also is not be able to understand this beyond the reason (Ghazāli 1970, 81).

The mystic knowledge, unlike the reasoning, is so wide and free of mistakes, doubts and dreams; and it leads to the certainty. The first way to find the mystic and illuminated knowledge is to remove barriers and veils in front of the eyes of the heart. The source of mystic knowledge is the heart and its means are filtration and purification of the soul; and it is obtained through the practical journey, edification and self-esteem. The first way to achieve spiritual enlightenment is pure nature and morality. When human gets rid of physical attributes, it becomes pure through the austerity and the attempt will achieve the knowledge which is beyond the understanding of those who just see the face of everything, and that understanding is mystical.

All Sufi sects and mystic cults, despite differences in some beliefs and methods as well as customs, have shared the same idea that the only ways to 
know the truth are heart intuition and mind purification. Sufi feels his heart truth, not through reasons and his mind.

The mystic believes that a whole life is an attempt to know the Self and to know the unity of human with God and to return to his essence. Life is a return journey to God, and is an evolutionary movement: the solid returns to the plant, plant changes to animal, and animal to human, and human to a superhuman, until it reaches to its source.

"Began a journey from yourself to the Self, That through such the soil of mine became gold" (Rūmi 2000, 3460-3464).

\section{Conclusion}

In this paper a comparative study of epistemological perspectives of two Gnostic and Islamic mysticism has been done and this fact is obvious that their points of view are the same; in other words, similarities between the two sects are so clear especially when the words "Gnosis" and "Erfän" are noticed. The word "Gnosis" is originally a Greek word meaning knowledge; "Erfān" also is derived from "Ma'refat" that is a kind of esoteric knowledge.

In Gnosticism, the true knowledge is the one that the reason does not get involved and can be obtained only through the heart. This knowledge is achieved when a person identifies himself, and is aware who he was, where he was, and in what person he is caught, and where he must go? The Gnostics believe that, the human soul is a divine and finite element imprisoned in the matter and the great task of human is to free this soul; the salvation obtained by the Gnosis.

Muslim mystics also believe that knowledge is the beginning of mysticism, but not the knowledge that obtained through the reasoning and science or books. The goal of 'Arif (Mystic) is to know God, but not through the senses and reason, because these two are limited and God is unlimited; so, the way of this knowledge is the pure heart and can be obtained through the revelation and illumination. Mystics believe that if humans know themselves, they will be able to know their God: He who knows himself already knows his Lord.

Similarities between Islamic mysticism and Gnosticism is so much that some believe the prominent position of the theory of knowledge in the minds of the early Sufis was due to the close contact with the Gnostics. 


\section{REFERENCES}

Al-Suyūți, A. A.-R. B.-A. (ND). Al-Jāme' Al-Ṣaghīr fi Ahādīth Al-Bashīr Al-Nazīr. Beirūt: Dār Al-Fekr.

Ashtiani, Jalal. 2007. 'Erfān. Tehrān: Enteshar.

'Atțār, F. 2005. Tadhkerat Al-Awliyā. Tehrān: Behzad.

Chittick, W. 2009. Sufism: A Short Introduction. Translated by Jalil Parvin. Tehran: Hekmat.

Corbin, H. 1979. Spiritual Body \& Celestial Earth: From Mazdean Iran to Shi'ite Iran. Translated by S. Dehshiri, Z. Tehran: Iranian Centre of Cultural Studies.

Corbin, H. 2008. The Man of Light in Iranian Sufism.Translated by F. Javaherinia. Tehran: Amuzgare Kherad.

Decret, F. 2004. Mani and Manichaeism. Translated by A. Bagheri. Tehran: Farzan. Duchesne-Guillemin, J. 1996. Religion of ancient Iran. Translated by R. Monajjem. Tehran: Fekre Rooz.

Freke, T \& Gandy, P. 2005. The Hermetica. The Lost Wisdom of the Pharaohs. Translated by F. Radmehr. Tehran: Nashre Markaz.

Gellman, J. 2017. "Mysticism The Stanford Encyclopedia of Philosophy (Summer 2019)." Edited by Edward N. Zalta. Metaphysics Research Lab, Stanford University. https://plato.stanford.edu/archives/sum2019/entries/ mysticism/

Ghazāli, A. I. M. 1970. Eterafate Ghazāli. Translated by Zein-aldin Kiaeininezhad. Tehrān: Ataei.

_-_. 2001. Kimiyaye Sa'ādat. Edited by H. Khadicjam. Tehrān: Elmi Farhangi.

Goldziher, I. 2007. "New Plato and Gnostic Thoughts in Hadith." Translated by R. Elahi Manesh. Haft Aseman 36:181-220.

Hanegraaff, W. J. 1967. Dictionary of Gnosis \& Western Esotericism. Leiden: Brill. Herbermann, Charles G. 1907. The Catholic Encyclopedia. New York: Robert Appleton Company.

Holroyd, S. 2008. The Elements of Gnosticism. Translated by A. Esmaeilpour. Tehran: Ostureh.

Hujwiri, A. A. I. U. 1997. The Kashf al-Mahjūūb. Edited by V. Zhukovskīı. Tehrān: Tahuri.

Ibn 'Arabi, M. I. A. ND.. Al- Futūḥāt al-Makkiyya. Beirūt: Dār al-Ehya. 
Jafari, Fereshteh, \& Ameri, M. 2017. "Impact of Gnosticism Among Muslim Mystics." Journal of Islamic Denominations 3: 143-159.

Jonas, H. 1991. The Gnostic Religion: The Message of the Alien God and the Beginnings of Christianity. Boston: Beacon Press.

Kondory, M. 2016. Hymn of the Pearl and Iranian Mysticism. Bokhara.

Lambdin, T. O., Turner, J. D., \& Wintermute, O. S. 2009. "The Nag Hammadi Library." The Gnostic Society Library. http://www.gnosis.org

MacRae, G. W. 1970. Essays on the Coptic Gnostic library. Leiden: Brill Archive.

Majlesi, M. B. I.-M. T. 1983. Behār Al-Anvār. Beirūt: Dār al-Ehya.

Mohammad, Poshtdae Ali \& Abbas Pour Xhormalu Mohammad Reza. 2012. "Epistemology in Islamic Mysticism and The Schools of Psychoanalyze." Pedagogic and Lyric In Persian Language and Literature Studies Quarterly 11: $103-126$

Motlagh, Abolghasem Esmailpour. 2000. "New look to the Iranian Culture." Hamshahri.

- - 2001. "The Myth of Creation in Manichaeism." Tehran: Karevan.

_-_. 2002. "A Comparative Study of the Spiritual Masnavi and the Manichaean Gnostic Poems." Specialized Journal of Language and Literature 25 (1/2): 171-190.

———. 2007. "The Hymns of Light." Tehran: Ostureh.

Naini, M. Reza Jalali. 2005. Dualists in Ancient Times. Tehran: Tahoor.

Nasr, S. H. 2016. "Epistemology in Islamic Philosophy." Translated by M. Jafari. http://www.cgie.org.ir/fa/news/128603

Nicholson, R. A. 2003. The Mysticism of Muslim Mystics. Translated by A. Azad. Mashhad: Ferdosi University Press.

Noss, J. B. 2011. Man's Religions. Translated by A. A. Hekmat. Tehran: Elmi Farhangi.

Quispel, G. 1992. "Hermes Trismegistus and the Origins of Gnosticism.” Vigiliae Christianae 46 (1): 1-19. https://brill.com/view/journals/vc/46/1/ article-p1_1.xml?language $=$ en

Qusheiri, A. A. I. H. 2008. Translation of the Ghoshairieh. Translated by Hasan Ibn Ahmad Osmani. Tehran: Zavar.

Rajablou, Z \& Alimi, M. 2017. "Allegorical Motifs-Mystical Gnostic in Book Jamshid and Khorshid Salman Savedji." Journal of Research Allegory in Persian Language and Literature 9 (33): 86-97. 
Robinson, J. M. 1981. "Nag Hammadi Library in English: The Definitive Translation of the Gnostic Scriptures." E.J. BRILL and Harper and Row. https://www.amazon.co.uk/Nag-Hammadi-Library-EnglishTranslation/dp/0060669357

Rūmi, J. ad-D. M. 1984. Masnavi-e Ma'navi. Edited by R. A. Nicholson. Tehrān: Mola.

———. 2000. Divan-e Shams Tabrīzi. Edited by B. Foruzanfar. Tehrān: Amir Kabir.

Shahbazi, H \& Abedi, M. 2020. "God-like Man Based on Sufism, Kabbalah and Gnosticism.” Ma'rifat-i Adyān 11 (3): 7-28.

Shīrāzi, S. al-Dīn. 1982. Arshyeh. Tehrān: Mola.

-—- 1987. Tafsir al-Qur'ān al-Karīm. Edited by M. Khajavi. Qom: Bidar.

Turner, J. D., \& Majercik, R. 2000. Gnosticism and Later Platonism: Themes, Figures, and Texts. USA: Society of Biblical Literature.

Wallis, R. T., \& Bregman, J. 1992. Neo-Platonism and Gnosticism. New York: State University of New York Press.

Williams, M. 2017. "Mysticism." https://www.britannica.com/topic/mysticism Zarrinkoub, A. 2011. The Research in Persian Sufism. Tehran: Amir Kabir.

_-_. 2011. Persian Sufism in its Historical Perspective. Translated by M. Keyvani. Tehran: Sokhan.

Zarrinkoub, R., \& Hoseini, T. 2018. "Ein Blick auf Eschatologische Individuelle Glauben in Gnostischen und Manichäischen Lehren." Spectrum Iran 31 (2): 9-28. 
Halaman ini sengaja dikosongkan 